\title{
Specific boundaries between the causal agents of the soybean stem canker
}

\author{
Eduardo A. Guillin'1, Pablo E. Grijalba ${ }^{2}$, Luiz Orlando de Oliveira ${ }^{3}$ \& Alexandra M. Gottlieb ${ }^{4,5}$ \\ ${ }^{1}$ Instituto de Genética Ewald A. Favret, CNIA, INTA Castelar, Buenos Aires, Argentina; ${ }^{2}$ Facultad de Agronomía, Universidad \\ de Buenos Aires, Buenos Aires, Argentina; ${ }^{3}$ Departamento de Bioquímica e Biologia Molecular, Universidade Federal de \\ Viçosa, 36570-900, Viçosa, MG, Brazil; ${ }^{4}$ Laboratorio de Citogenética y Evolución (LaCyE), Departamento de Ecología, \\ Genética y Evolución, Facultad de Ciencias Exactas y Naturales, Universidad de Buenos Aires, Buenos Aires, Argentina; \\ ${ }^{5}$ Consejo Nacional de Investigaciones Científicas y Técnicas (CONICET), Buenos Aires, Argentina
}

Author for correspondence: Eduardo A. Guillin, e-mail: guillin.eduardo@inta.gob.ar

\begin{abstract}
Pathogens within the Diaporthe complex cause seed decay, stem blight and stem canker on soybean, representing a serious threat for this crop species. We herein utilize worldwide sequence data retrieved from Genbank in order to assess the species boundaries between the soybean stem canker causal agents, and define whether or not they should be regarded as members of the same biological species. These studies were complemented with compatibility tests, in order to validate our findings from a biological standpoint. Species delimitation assays supported the occurrence of a speciation event between $D$. caulivora and D. phaseolourm var. meridionalis. A speciation hypothesis between $D$. aspalathi and $D$. phaseolourm var. meridionalis was also supported, based on three reciprocally monophyletic substitutions at locus EF1- $\alpha$. Compatibility tests further validated species delimitation assays indicating that $D$. caulivora has developed barriers to gene exchange with $D$. phaseolorum var. meridionalis. Clarification of the specific boundaries of the SSC pathogens and related entities will be an important asset to future research in soybean pathology, epidemiology and breeding.
\end{abstract}

Key words: Diaporthe aspalathi, Diaporthe caulivora, Diaporthe phaseolorum var. meridionalis, species delimitation.

\section{INTRODUCTION}

Diaporthe Nitschke, with over 800 specific names, constitutes the teleomorphic state of Phomopsis (Sacc.) Bubák, an anamorphic genus with more than 900 specific names recorded. An important number of species within this group has been reported as destructive pathogens causing cankers, diebacks, root rots, fruit rots, leaf spots, blights, decay and wilts on a wide range of plant hosts worldwide, including strategic crop species (Udayanga et al., 2011; 2012). Fungi in the Diaporthe species complex constitute an economically relevant threat for the soybean production chain worldwide, with five taxa traditionally recognized: Diaporthe phaseolorum (Cooke \& Ellis) Sacc., D. phaseolorum var. sojae (Lehman) Wehm., Phomopsis longicolla Hobbs, D. phaseolorum var. meridionalis F. A. Fernández, D. phaseolorum var. caulivora Athow \& Caldwell. The latter two have been reported as the causal agents of the soybean stem canker (SSC). Santos et al. (2011) recently described Diaporthe novem Santos, Vrandecic \& Phillips, as a sixth soybean pathogen. Before the arrival of soybean rust to the Americas Diaporthe pathogens were cited as causing more economic losses in soybean production than any other single fungal pathogen, and had been a major concern in South America since 1989 (Sinclair \& Backman, 1989). During the 1994/1995 growing season, yield losses due to SSC reached US\$ 170 million in Brazil (Yorinori, 1996). SSC was first detected in Argentina in $1996 / 97$, and has since then caused up to $100 \%$ yield loss in some instances (Grijalba et al., 2011).

Asexual and sexual names of fungi have recently been granted equal status in the International Code of Nomenclature for algae, fungi, and plants. Therefore, the name Diaporthe has been adopted for this group of fungi, regardless of the spore stage involved (Santos et al., 2011; Crous et al., 2011; Udayanga et al., 2012; Gomes et al., 2013) since Diaporthe (1870) predates Phomopsis (1905).

The taxonomic history of Diaporthe species as soybean pathogens starts early in the 20th century when Diaporthe spp. isolates were obtained from a group of unrelated hosts, including Ipomoea batata L., Phaseolus lunatus L. and Glycine $\max$ (L.) Merr. Following the hostspecific hypothesis, those isolates were recognized as independent species and identified as Diaporthe batatas Harter \& E. C. Field; D. phaseolorum (Cooke \& Ellis) Sacc., and D. sojae Lehman, respectively (Morgan-Jones, 1985; 1989; Backman et al., 1985). In contrast, Harter \& Field (1912) and Harter (1917) proposed that these three pathogens constitute a single species, reassigning them as three varieties: $D$. phaseolorum var. phaseolorum, $D$. phaseolorum var. batatas, and D. phaseolorum var. sojae. In the early 1950 's, $D$. phaseolorum var. caulivora was 
first described as the causal agent of the SSC and it was considered a perithecial variant from $D$. phaseolorum var. batatas (Crall, 1950), the causal agent of the dry root in sweet potato (Ipomea batata L.). Hobbs \& Phillips (1985) proposed the differentiation of the US Northern and Southern stem cankers. Morgan Jones (1989) further split them into formae speciales, based on morphological and physiological differences, designating $D$. phaseolorum f. $s p$. meridionalis for the southern US teleomorphic isolates, and $D$. phaseolorum $f$. sp. caulivora for northern isolates. Fernández \& Hanlin (1996), based on differences in the number and type of lesions shown by field-grown plants, readopted the concept of "variety". Since then, the accepted denomination has been $D$. phaseolorum var. caulivora and D. phaseolorum var. meridionalis. Based on nucleotide sequence data, cultural, phytopathological and morphological evidence, Rensburg et al. (2006) proposed that $D$. phaseolorum var. meridionalis should be treated at the species level along with the red bush die-back causal agent, Diaporthe aspalthi. Due to nomenclature reasons they renamed $D$. phaseolorum var. meridionalis as Diaporthe aspalathi Janse Rensburg, Castlebury \& Crous. More recently Santos et al. (2011) raised D. phaseolorum var. caulivora to the specific level, recombining it as Diaporthe caulivora (Athow \& Caldwell) J.M. Santos, Vrandecic \& A.J.L. Phillips. This puzzling taxonomic situation has rendered the identification of biological entities from amongst the array of specific names extremely cumbersome.

Species identification in Diaporthe has been traditionally based on host specificity (Udayanga et al., 2011;2012). Few morphological characters can undoubtedly differentiate among taxa (Uecker, 1988). Identification of the SSC pathogens has relied on colony appearance, growth rate, size of stromata, arrangement and morphology of perithecia, presence of $\alpha$ and $\beta$ conida, and detection of the anamorph phase (Morgan Jones, 1985; 1989; Sinclair \& Backman, 1989; Fernandez \& Hanlin, 1996). The overlap shown by some of these quantitative features has led to several ambiguous identifications. Indeed, it is a well-known general fact, that morphological and phytopathological characters are affected by environmental factors and sampling, often leading to inaccurate species classification (Davis \& Nixon, 1992; Padial et al., 2010; Grijalba \& Ridao, 2012). In order to circumvent such limitations, the classification of Diaporthe species is presently being redefined to include DNA sequence data (Rehner \& Uecker, 1994; Zhang et al., 1998; Mostert et al., 2001; Farr et al., 2002; Santos et al., 2010).

Nevertheless, methods for species delimitation using genealogical data typically rely upon genetic distances or gene trees (Sites \& Marshall, 2003; 2004). This analytical approach requires arbitrary decisions regarding the thresholds of the species boundary (Hey, 2009). In order to circumvent this problem Yang \& Rannala (2010) developed a coalescent-based approach to delimitate closely related species using DNA sequence data. This methodology includes both intra and interspecific variation. This approach to species boundary delimitation has been validated with simulated datasets (Yang \& Rannala, 2010; Zhang et al., 2011) and applied to empirical datasets of rotifers, lizards (Yang \& Rannala, 2010), forest geckos (Leache \& Fujita, 2010), butterflies (Zhang et al., 2011) and rice (Zang et al., 2011).

The study of somatic incompatibility reactions provides a useful criterion for spatial delimitation of fungal individuals, or at least for delimitation of genetically distinct mycelia. This criterion has been applied in several fungal groups including important plant-pathogenic fungi (Pál et al., 2007). It has been proposed that the incompatibility reaction may limit the spread of harmful cytoplasmic or nuclear elements (Caten, 1972), and prevent resource plundering (Debets \& Griffiths, 1998). It has also been suggested that vegetative incompatibility may promote the initiation of sexual reproduction in some species as a result of non-self recognition (Dyer et al., 1992). Individuals that share the same heterokaryon or vegetative incompatibility loci can fuse to form a heterokaryon and are then considered to belong to the same vegetative compatible group (Glass et al., 2000). In contrast, fungal isolates that differ at one or more of these loci will not fuse. Instead, programmed cell death or apoptosis occurs in the mycelial cells that are in contact with an isolate representing different vegetative compatible groups (Leslie, 1993). Previous vegetative compatibility assays have been performed for the SSC pathogens, but involving solely two Brazilian isolates (Costamilan et al., 2008).

As previously mentioned, the taxonomic rank for both SSC causal agents has been upraised to the specific level. Nevertheless, genetic and biological boundaries between them have not been addressed so far; indeed, the causal agents of tSSC are in practice still treated as part of the same biological species by soybean breeders and pathologists. As a consequence, much of the research carried out elsewhere treats these pathogens as a single biological entity. We used molecular data retrieved from many different geographic origins in order to clearly assess whether the gene pools of $D$. aspalathi, D. phaseolorum var. meridionalis and $D$. caulivora are in fact isolated or not. To further biologically validate the molecular evidence, we implemented vegetative compatibility assays between distinct soybean isolates of $D$. phaseolorum var. meridionalis and D. caulivora.

\section{MATERIALS AND METHODS}

\section{Preliminary nucleotide sequence analyses and dataset assembly}

Sequence data for soybean pathogen isolates originally identified as Diaporthe phaseolorum var. caulivora, Diaporthe caulivora, Diaporthe phaseolroum var. meridionalis and Diaporthe aspalathi were retrieved form Genebank. Sequence data publicly available for seven 
loci was included for molecular species delimitation assays (Table 1). Multiple sequence alignment for each locus was attempted using Clustal W (Thompson et al., 1994) and Muscle (Edgar, 2004), as implemented in Mega 5.0 (Tamura et al., 2007), with different parameter settings, and slight manual modifications when necessary.

TABLE 1 - Locus name, original GenBank denomination, host, country of origin and GenBank accession numbers of the sequences included in this study.

\begin{tabular}{|c|c|c|c|c|}
\hline Locus name & Original Taxon name (GenBank) & Host & $\begin{array}{c}\text { Country of } \\
\text { origin }\end{array}$ & GenBank accession number \\
\hline \multirow[t]{6}{*}{$28 \mathrm{~S}$} & Diaporthe caulivora & Glycine $\max$ & USA & JQ697877 \\
\hline & & Glycine $\max$ & Serbia & JQ697878, JQ697879, JF411057, JF411058 \\
\hline & & Glycine $\max$ & Italy & HQ445920, HQ445921 \\
\hline & & & & HQ445936 \\
\hline & Diaporthe phaseolorum var. meridionalis & Glycine $\max$ & Italy & HQ445934, HQ445935 \\
\hline & & Glycine $\max$ & USA & JQ697875 / JF704178 \\
\hline \multirow[t]{3}{*}{ CAL } & Diaporthe caulivora & Glycine $\max$ & Croatia & KC343287 \\
\hline & & Glycine soja & Canada & KC343288 \\
\hline & Diaporthe aspalathi & Aspalathus linearis & South Africa & KC343277 / KC343279 \\
\hline \multirow[t]{3}{*}{ HIS 3} & Diaporthe caulivora & Glycine $\max$ & Croatia & KC343529 \\
\hline & & Glycine soja & Canada & KC343530 \\
\hline & Diaporthe aspalathi & Aspalathus linearis & South Africa & KC343519, KC343521 \\
\hline \multirow[t]{3}{*}{$\beta$-TUB } & Diaporthe caulivora & Glycine $\max$ & Croatia & KC344013 \\
\hline & & Glycine soja & Canada & KC344014 \\
\hline & Diaporthe aspalathi & Aspalathus linearis & South Africa & KC344003 / KC344005 \\
\hline \multirow[t]{13}{*}{ EF1- $\alpha$} & Diaporthe phaseolorum var. caulivora & Glycine $\max$ & South Korea & HQ333508 \\
\hline & & Glycine $\max$ & USA & AF398889, JQ697864 \\
\hline & Diaporthe caulivora & Glycine $\max$ & Croatia & KC343771, HM347687 / \\
\hline & & & & HM347691 \\
\hline & & Glycine $\max$ & Italy & HQ445914 \\
\hline & & Glycine $\max$ & Serbia & JQ697852, JF461465 / JF461467 \\
\hline & & Glycine soja & Canada & $\mathrm{KC} 343772$ \\
\hline & Diaporthe aspalathi & Aspalathus linearis & South Africa & AY339353, DQ286249 / DQ286252, \\
\hline & Di. $\quad$ g the & & & KC343761 / KC343763 \\
\hline & Diaporthe phaseolorum var. meridionalis & Glycine $\max$ & USA & $\begin{array}{l}\text { AF394864, AF394865 , AF398890 / } \\
\text { AF398893 }\end{array}$ \\
\hline & & Glycine $\max$ & Italy & HQ445932 \\
\hline & & Glycine max & USA & JF461479, JF461480 \\
\hline & & Glycine $\max$ & Serbia & JQ697862 JQ697863 \\
\hline \multirow[t]{2}{*}{ IGS } & Diaporthe phaseolorum var. caulivora & Glycine $\max$ & Argentina & HM769302 / HM769322 \\
\hline & Diaporthe phaseolorum var. meridionalis & Glycine $\max$ & Argentina & HQ130442/ HQ130444 \\
\hline \multirow[t]{26}{*}{ ITS } & Diaporthe phaseolorum var. caulivora & Glycine $\max$ & Ex-Yugoslavia & AJ312360 \\
\hline & & Abutilon theophrasti & Serbia & AY857867 \\
\hline & & Glycine $\max$ & China & EF594039 \\
\hline & & Glycine $\max$ & Argentina & EF594040, EF594041 \\
\hline & & Glycine $\max$ & USA & EF594042, EF594043 \\
\hline & & Glycine $\max$ & Brazil & EU622854, FJ357156 / FJ357158 \\
\hline & & Glycine max & Argentina & HM625752 / HM625773 \\
\hline & & Glycine $\max$ & USA & AF000212, AF000563, AF000567 \\
\hline & & Glycine $\max$ & South Korea & HQ333503 \\
\hline & Diaporthe caulivora & Glycine $\max$ & Serbia & JF418934 / JF418937 \\
\hline & & Dipsacus laciniatus & Croatia & $\begin{array}{l}\text { HM347703, HM347704, } \\
\text { HM347712 }\end{array}$ \\
\hline & & Glycine $\max$ & Italy & HQ445937 \\
\hline & & Glycine $\max$ & USA & JQ697851 \\
\hline & & Glycine $\max$ & Croatia & KC343045 \\
\hline & & Glycine soja & Canada & $\mathrm{KC} 343046$ \\
\hline & Diaporthe aspalathi & Aspalathus linearis & South Africa & AY339321, DQ286275 / DQ286278 - \\
\hline & & & & FJ785432, KC343035 / KC343037 \\
\hline & Diaporthe meridionalis & Glycine $\max$ & USA & AF001015, AF000564 /AF000566 \\
\hline & & Glycine $\max$ & Italy & AJ312361 \\
\hline & Diaporthe phaseolorum var. meridionalis & Glycine $\max$ & China & EF594044 \\
\hline & & Glycine $\max$ & Brazil & FJ357153 / FJ357155 \\
\hline & & Glycine $\max$ & Argentina & HQ130438 / HQ130440 \\
\hline & & Glycine $\max$ & USA & JF430485, JF430486 \\
\hline & & Glycine $\max$ & Italy & JF495106 \\
\hline & & Glycine $\max$ & Serbia & JQ697849, JQ697850 \\
\hline & & $\begin{array}{l}\text { Melastoma } \\
\text { malabathricum }\end{array}$ & India & KF193982 \\
\hline
\end{tabular}

28 S: 28S ribosomal RNA gene; CAL: Calmodulin gene; HIS 3: histone H3 gene; $\beta$-TUB: beta-tubulin gene; EF1- $\alpha$ : translation elongation factor 1 alpha gene; IGS: Intergenic Spacer of the nrDNA region; ITS: internal transcribed spacer regions of the nrDNA and intervening 5.8S nrDNA. Slashes indicate consecutive accession numbers. 


\section{Bayesian species delimitation assays}

Species delimitation assays were performed using the program Bayesian Phylogenetics and Phylogeography (BPP) v. 2.0 (Rannala \& Yang, 2003; Yang \& Rannala, 2010). This program requires three input files, namely the sequence file (including multiple alignments for every loci under consideration), a species map file (indicating the putative species for each sequence) and a file including specific evolutionary parameters. This latter file is amenable to alternative tailoring in order to account for different evolutionary scenarios. Evolutionary parameters include a guide tree, as well as specification of prior distributions for the scaled ancestral population size $\left(\theta_{0}\right)$, and root age $\left(\tau_{0}\right)$. Priors are assigned a Gamma $\mathrm{G}(\alpha, \beta)$ distribution, with a prior mean $=\alpha / \beta$ and prior variance $=\alpha / \beta^{2}$. This information is user-provided, and constitutes the starting point (priors) for the program. Prior distributions can affect the posterior probabilities for the different speciation models (topologies). According to coalescence theory, large values for $\theta_{0}$ (big population numbers) and small values for $\tau_{0}$ (shallow divergence times) favor conservative models containing fewer species (Leache \& Fujita 2010; Yang \& Rannala, 2010). In species delimitation, the guide phylogeny is also a most important prior affecting posterior probabilities for the speciation hypotheses (Leache \& Fujita, 2010; Yang \& Rannala, 2010; Zang et al., 2011).

BPP v. 2.0 uses a reversible-jump Markov chain Monte Carlo (rjMCMC) algorithm to jump back and forward over different topologies and estimate the posterior distributions of species delimitation models, starting from the guide tree. Every model should be compatible with the starting priors and the sequence alignment introduced in the input files. By default, BPP assumes no admixture following a speciogenic event. The JC69 mutation model (Jukes \& Cantor, 1969) is assumed to accommodate multiple hits. The sequences are supposed to be close, so that JC69 is deemed adequate. Leache \& Fujita (2010) proposed posterior probability values $>0.95$ as strong support for a speciation event.

The guide tree herein proposed considers $D$. aspalathi, D. phaseolorum var. meridionalis and $D$. caulivora as three separate species (completely resolved tree). Considering the huge population numbers of fungal organisms, a gamma prior distribution $\mathrm{G}(1,10)$ for the root population size $\left(\theta_{0}\right)$ was set for every assay. Provided that no information (eg. fossil record) is available indicating species history, three different gamma priors, namely $\mathrm{G}(1$, $10), G(2,200)$ and $G(2,2000)$, were attempted for $\tau_{0}$. These priors account for different divergence times from the root population. Each analysis was run at least twice, to confirm consistency between runs. Running the rjMCMC analyses for 500,000 generations (sampling interval of five) with a burn-in period of 10,000 produced consistent results across separate analyses initiated with different starting seeds. Convergence was considered as adequate only after the Estimated Sample Size (ESS) was above 300 for every node.

\section{Somatic compatibilty tests}

Vegetative compatibility was tested based on the formation of a barrage-zone. Six soybean fungal isolates were tested against each other. All isolates are housed at the Phytopathology Lab, School of Agronomy, University of Buenos Aires. Diaporthe phaseolorum var. meridionalis isolates were obtained at Asunción (Paraguay; Genbank accession number HQ130438, Dm1); Venado Tuerto (Santa Fe, Argentina; HQ130439, Dm2) and Pergamino (Buenos Aires, Argentina; HQ130440, Dm3). Diaporthe caulivora isolates were obtained at Trenque Lauquen (Southern Buenos Aires, Argentina, HM625758, Dc1), Urdampilleta (Western Buenos Aires, Argentina, HM625770, Dc2) and General Pirán (Buenos Aires, Argentina, HM625760, Dc7). Isolates were paired $2-3 \mathrm{~cm}$ apart on PDA (potato dextrose agar) in Petri dishes and incubated in darkness for a week at $20^{\circ} \mathrm{C}$ and another week at $25^{\circ} \mathrm{C}$ (Costamilan et al., 2008). Self-crosses were utilized as negative controls, representing no barrage formation. Each pairing was repeated twice. Hyphal interactions were recorded two weeks after the fungi were plated. The interaction zone and their boundaries were further observed under the microscope and photographed.

\section{RESULTS}

\section{Sequence analysis}

In the present study we included 162 sequences from 7 distinct nuclear loci, comprising a total of $76240 \mathrm{bp}$. ITS and EF1- $\alpha$ were the only genomic locations with sequences available for all taxa under study.

\section{Bayesian species delimitation assays}

Multilocus bayesian species delimitation assays, irrespective of time divergence assumptions, yielded posterior probabilities (pp) between $99-100 \%$ for the completely resolved tree in every evolutionary scenario (Figure 1). In comparison, the two-species (considering $D$. aspalathi and $D$. ph. var. meridionalis as a single species) model displayed extremely low posterior probabilities under all prior combinations ( $\mathrm{pp}<0.02$ in all cases).

A speciation hypothesis between $D$. aspalathi and $D$. phaseolorum var. meridionalis was also strongly supported $(\mathrm{p} p=0.99-1.0$, Figure 1) using the original three species guide tree, and under every time divergence assumption. In order to further explore this finding, a series of assays aimed at assessing the species boundaries between $D$. aspalathi and D. phaseolorum var. meridionalis were carried out, using solely those loci for which information was available for both taxa (ITS and EF1- $\alpha$ ). A speciation hypothesis was once again favored $(\mathrm{pp}>0.99)$ in every evolutionary scenario. This speciation hypothesis is sustained by three reciprocally monophyletic substitutions between $D$. aspalathi and $D$. phaseolorum var. meridionalis at positions g. $99 \mathrm{G}>\mathrm{T}$, g. $161 \mathrm{C}>\mathrm{T}$ and g.236 $\mathrm{C}>\mathrm{T}$ of the EF1- $\alpha$ locus (Figure 2). The ITS region, on the other hand, 


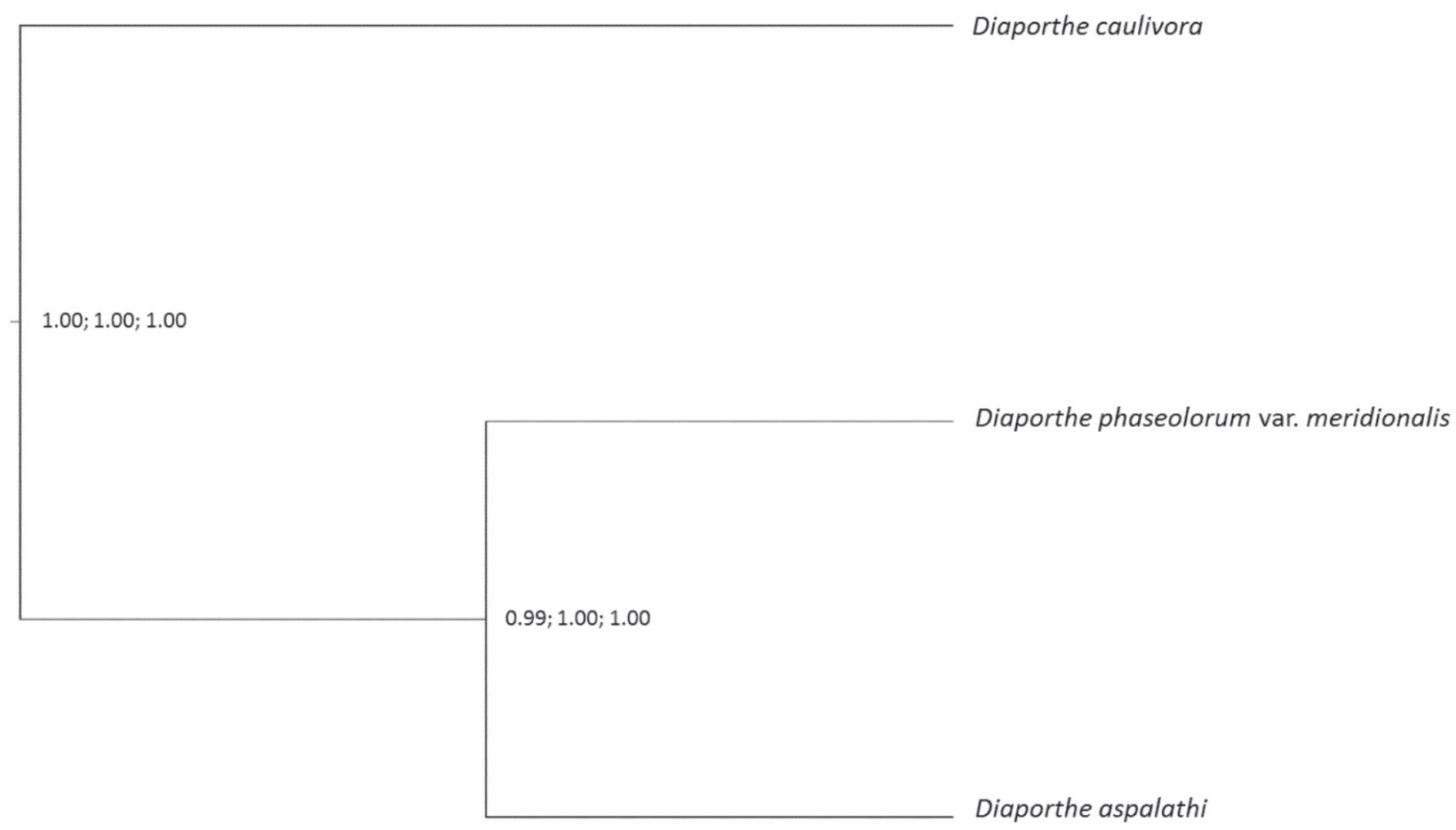

FIGURE 1 - Multilocus Bayesian species delimitation results assuming a 3-species guide tree. The speciation probabilities are provided for each node and each combination of priors. Prior mean $\theta=0.1$ in all cases (big population numbers); this assumption results in lower speciation probabilities. Left, prior mean $\tau_{0}=0.1$; middle, prior mean $\tau_{0}=0.01$; right, prior mean $\tau_{0}=0.001$.

was identical between $D$. aspalathi and $D$. phaseolorum var. meridionalis, as previously stated (Rensburg et al., 2006).

\section{Somatic compatibility tests}

The vegetative compatibility tests were performed between $D$. caulivora and D. phaseolorum var. meridionalis isolates (Figure 3). The presence of a distinctive barrage, or pigmented zone and a lytic gap along the contact zone was detected in every $D$. caulivora $-D$. phaseolorum var. meridionalis confrontation assayed, seven days after contact. Microscopically, this pigmented zone comprised of a combination of compartimentalized hyphal segments, vacuolated brown hyphae and empty cells, not observed in unpaired growing mycelia. Conversely, D. phaseolorum var. meridionalis $-D$. phaseolorum var. meridionalis and $D$. caulivora $-D$. caulivora confrontations merged uniformly with no dark line in the contact zone.

\section{DISCUSSION}

The multilocus species delimitation test herein assayed clearly indicates that no gene exchange occurs between $D$. caulivora and the $D$. aspalathi $-D$. phaseolorum var. meridionalis cluster. Incompatibility reactions in every $D$. caulivora - D. phaseolorum var. meridionalis confrontation further strongly validate and confirm the genetic isolation between both groups. These findings supports previous results from Santos et al. (2011) who raised $D$. caulivora to the specific level using isolates from Croatia, and Grijalba et al. (2011) and Guillin et al. (2011) who reached a similar conclusion for Argentinean isolates.

Our species delimitation assays also supported a speciation hypothesis between $D$. aspalathi and $D$. phaseolorum var. meridionalis. This result is somehow unexpected, since it contradicts previous claims by Smit \& Knox-Davies (1989a; 1989b) and Rensburg et al. (2006), who concluded that both taxa should be considered as part of the same species. These authors have mainly based their proposal on comparative morphology between the two taxa, and an ITS-based phylogenetic reconstruction including other Diaporthe species as well; no EF1- $\alpha$ sequences from D. phaseolorum var. meridionalis was available to them, and therefore they were not included in their combined ITS and EF1- $\alpha$ phylogenetic reconstruction. Therefore, although it is evident that these two taxa are very closely related, it is still not clear whether they are reproductively compatible. In this regard, it should be emphasized that $D$. aspalathi has solely been obtained from the red bush, Aspalathus linearis (Burm. f.) R. Dahlgren in South Africa, whereas isolates identified as $D$. phaseolorum var. meridionalis have been obtained from soybean fields worldwide. The occurrence of three reciprocally monophyletic substitutions at EF1- $\alpha$ suggests that both taxa have been somehow isolated for a considerable period of time, relative to the population 


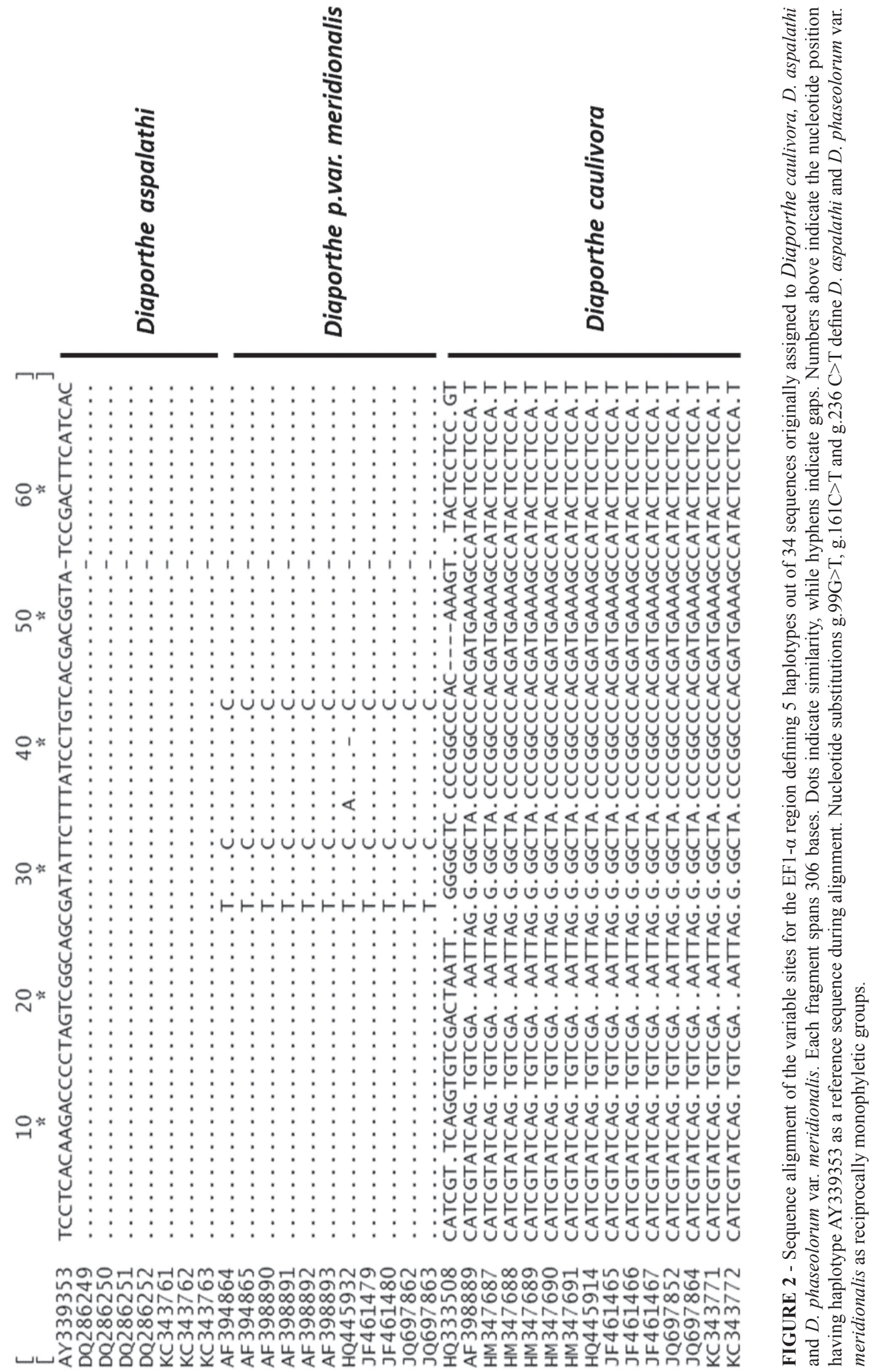




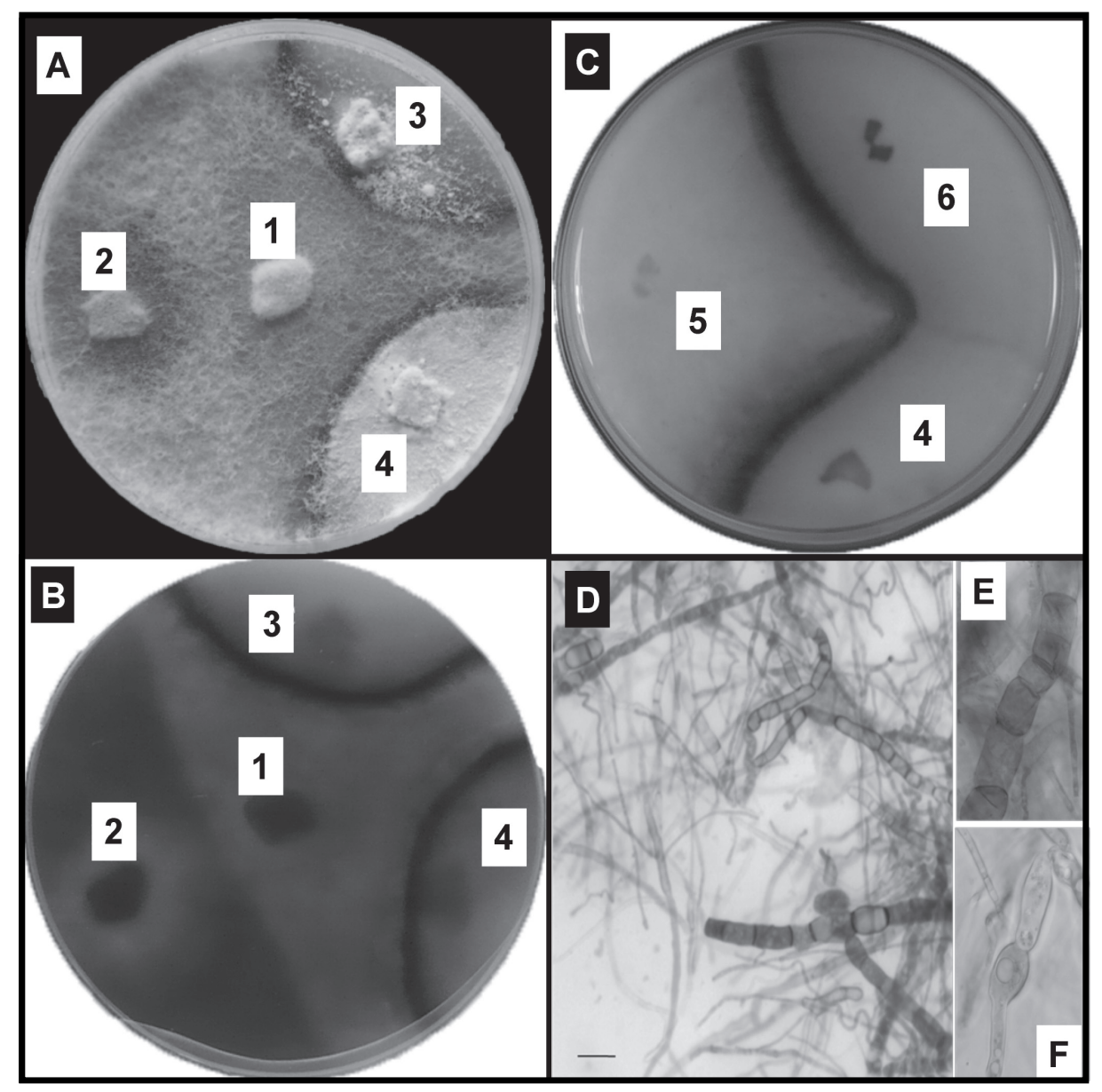

FIGURE 3 - $\quad$ Somatic incompatibility assays between Diaporthe phaseolorum var. meridionalis obtained from soybean fields) and D. caulivora isolates. A. B. Front and reverse of the mycelia growing in PDA: 1, D. phaseolorum var. meridionalis (HQ130439, Argentina); 2, D. phaseolorum var. meridionalis(HQ130438, Paraguay); 3, D. caulivora (HM625760, Argentina); 4, D. caulivora (HM625758, Argentina); C. Reverse of the mycielia growing in PDA: 5, D. phaseolorum var. meridionalis (HQ130440, Argentina); 6, D. caulivora (HM625770, Argentina). The darkened contact zone represents barrage formation. D-F. Hyphae from the barrage zone from confrontation HM625770 vs HQ130440; D. Thin and thickened brown hyphae; E. String of empty brown cells; F. Vacuolized cells. Bar $=10 \mu \mathrm{m}$. size at the founder event (most likely a host jump from soybean to red bush). The present results suggest that genetic divergence between these two groups might be currently taking place, based on ecological grounds (host specialization). Therefore, it cannot be excluded that $D$. aspalathi and D. phaseolorum var. meridionalis constitute cryptic species at present. Further analyses with a larger number of loci are warranted, in order to assess whether a host-jump based speciation event between these two taxa has already been accomplished. No compatibility or cross infection tests involving $D$. phaseolorum var. meridionalis and $D$. aspalathi isolates have been attempted so far to our knowledge in order to biologically validate contrasting hypotheses. Although D. phaseolorum var. meridionalis has been formally accepted as a synonym of $D$. aspalathi, in view of the present results it is likely that this will need to be further clarified in the future.

It has been stated that traditional morphological characters no longer clarify the taxonomy of Diaporthe at the specific level (Brayford, 1990; Rehner \& Uecker, 1994; Crous, 2005). In this regard, Udayanga et al. (2011; 2012) and Gomes (2013) proposed phylogenetic trees as platforms for future taxonomic classification within this species complex. Nevertheless, speciation is a continuous process (De Queiroz, 1998; 2007) and this implies that delimiting species using genealogical data will necessarily be accompanied by some degree of uncertainty (Leache \& Fujita, 2010). This is particularly so when dealing with closely related species. Very importantly also, multiple sequence alignment for a great number of species would most likely bring about ambiguously aligned regions that could greatly skew subsequent phylogenetic analyses (Morrison, 2009), since the characters (nucleotide positions) within will most likely be homoplasic. The number of taxa included not only affects multiple alignment, but also support (or probability) values, and eventually cluster resolution within the topology. This is why multi-species phylogenetic reconstructions shall only be considered as preliminary backbones for further fine-scale analysis such as species boundary delimitations within a particular group of organisms.

Our species delimitation study for the SSC causal agents reveals the potential of the coalescent-based approach for recognizing speciation events for problematic taxa, or groups for which traditional methodologies are not clear-cut due to experimental or historical reasons. This 
is, to our knowledge, the first attempt to using both infra and supra-specific data for species boundary assessment in plant pathogenic fungi. We propose that the inclusion of a coalescent-based methodology for species delimitation will greatly contribute to the resolution of Diaporthe species complex taxonomy. Additionally, this approach might be a great asset at establishing anamorph-teleomorph connections, an issue greatly lagging in Diaporthe, where only $20 \%$ of such links have been resolved so far (Udayanga et al., 2011).

Precise resolution of species boundaries will greatly contribute to optimizing downstream academic and applied studies. It is important to note that we herein adopt the traditional biological species concept (reproductive isolation amongst taxa) based on purely practical grounds: elucidation of the biological relationships amongst the SSC pathogens has implications for agricultural research. Should, for instance, D. aspalathi and D. phaseolorum var. meridionalis still share their gene pools, different hosts (soybean, red bush) might act as alternative sources of inocula; this should not be disregarded by producers and sanitary authorities. This could in turn contribute to the dissemination of a particular disease into new crops species and geographic areas.

Clarification of whether or not a given group of pathogens are reproductively isolated might be an indication of substantially different epidemiological conditions required by the individual taxa, as well as differential preconditions for breeding activities and strategies. In this regard, five loci have been so far described in soybean as conferring vertical resistance against $D$. phaseolorum var. meridionalis, whereas no major gene conferring resistance against $D$. caulivora has been described. Because of the cumbersome taxonomic history of the group, these five loci had paradoxically been named as " $R d c$ " (resistance against "D. caulivora"). Pioli et al. (2003) suggested that these loci should be renamed as " $R d m$ " (Resistance against " $D$. phaseolorum var. meridionalis"). According to the present results, $R d m$ gene stacking aimed at increasing resistance against $D$. caulivora, for instance, should not be considered as an appropriate breeding strategy, and this approach should not be favored within corporate or public breeding programs in the future.

\section{ACKNOWLEDGEMENTS}

We wish to thank the Joint MERCOSUR Research Program for supporting authors meetings both in Brazil and Argentina, with regards to the elaboration of the present manuscript. L.O.O. acknowledges a fellowship (PQ 305710/2009-5) from Conselho Nacional de Desenvolvimento Científico e Tecnológico - CNPq and a grant (PPM-00148-09) from Fundação de Amparo à Pesquisa do Estado de Minas Gerais - FAPEMIG. We also wish to express our gratitude to Bibiana Ferrari, Ezequiel Pozzo and Marcos Quiroga from Don Mario Seeds for their kind contribution to the present research project.

\section{REFERENCES}

Backman PA, Weaver DB, Morgan-Jones G (1985) SSC: an emerging disease. Plant Disease 69:641-647.

Brayford D (1990) Variation in Phomopsis isolates from Ulmus species in the British Isles and Italy. Mycological Research 94:691-697.

Caten CE (1972) Vegetative incompatibility and cytoplasmic infection in fungi. Journal of General Microbiology 72:221-229.

Costamilan LM, Yorinori JT, Almeida AM, Seixas CDS, Binneck E, Araújo M, Carbonari J (2008) First report of Diaporthe phaseolorum var. caulivora infecting soybean plants in Brazil. Tropical Plant Pathology 33:381-385.

Crall JM (1950) Soybean disease in Iowa in 1949. Plant Disease Reporter 34:96-97.

Crous PW (2005) Impact of molecular phylogenetics on the taxonomy and diagnostics of fungi. EPPO Bulletin 35:47-51.

Crous PW, Groenewald JZ, Shivas RG, Edwards J, Seifert KA, Alfenas AC, Alfenas RF, Burgess TJ, Carnegie AJ, Hardy GEStJ, Hiscock N, Huberli D, Jung T, Louis-Seize G, Okada G, Pereira OL, Stukely MJC, Wang W, White GP, Young AJ, McTaggart AR, Pascoe LG, Porter W, Quaedvlieg W (2011) Fungal Planet description sheets 69-91. Persoonia 26:108-156.

Davis JI, Nixon KC (1992) Populations, genetic-variation, and the delimitation of phylogenetic species. Systematic Biology 41:421435.

De Queiroz K (1998) The general lineage concept of species, species criteria, and the process of speciation: a conceptual unification and terminological recommendations. In: Howard DJ, Berlocher SH (Eds.) Endless forms: Species and speciation. Oxford, UK. Oxford University Press. pp. 57-75.

De Queiroz K (2007) Species concepts and species delimitation. Systematic Biology 56:879-886.

Debets AJM, Griffiths AJF (1998) Polymorphism of het-genes prevents resource plundering in Neurospora crassa. Mycological Research 102:1343-1349.

Dyer PS, Ingram DS, Johnstone K (1992) The control of sexual morphogenesis in the Ascomycotina. Biological Reviews 67:421458.

Edgar RC (2004) MUSCLE: multiple sequence alignment with high accuracy and high throughput. Nucleic Acids Research 32:1792-1797.

Farr DF, Castlebury LA, Rossman AY, Putnam ML (2002) A new species of Phomopsis causing twig dieback of Vaccinium vitisidaea (lingonberry). Mycological Research 106:745-752.

Fernández FA, Hanlin RT (1996) Morphological and RAPD analyses of Diaporthe phaseolorum from soybean. Mycologia 88:425-440.

Glass NL, Jacobson DJ, Shiu PKT (2000) The genetics of hyphal fusion and vegetative incompatibility in filamentous ascomycete fungi. Annual Review of Genetics 34:165-186.

Gomes RR, Glienke C, Videira SI, Lombard L, Groenewald JZ, and Crous PW (2013) Diaporthe: A genus of endophytic, saprobic and plant pathogenic fungi. Persoonia 31:1-41.

Grijalba PE, Ridao A (2012) Survival of Diaporthe phaseolorum 
var. caulivora (causal agent of soybean stem canker) artificially inoculated in different crop residues. Tropical Plant Pathology 37: 271-274.

Grijalba PE, Ridao A, Guillin EA (2011) Caracterización taxonómica y análisis de la variabilidad del agente causal del cancro del tallo de la soja en la Provincia de Buenos Aires (2005/2007). Revista de Investigaciones Agropecuarias 37:290-297.

Guillin EA, Grijalba PE, Gottlieb AM (2011) Agentes causales del cancro del tallo de la soja: Dos especies diferentes? In: Quinto Congreso de la Soja del Mercosur, Resumos Rosario, Argentina. pp. 197-202.

Harter L (1917) Pod blight of the lima bean caused by $D$. phaseolorum. Journal of Agricultural Research 11:473-504.

Harter L, Field E (1912) Diaporthe, the ascogenous form of sweet potato dry rot. Phytopathology 2:121-124.

Hey J (2009) On the arbitrary identification of real species. In: Butlin RK, Bridle JR, Schluter D (Eds.) Speciation and patterns of diversity. Cambridge, UK. Cambridge University Press. pp. 15-28.

Hobbs T, Phillips D (1985) Identification of Diaporthe and Phomopsis from soybean. Phytopathology 75:500.

Jukes TH, Cantor CR (1969) Evolution of Protein Molecules. New York, NY, USA. Academic Press.

Leache AD, Fujita MK (2010) Bayesian species delimitation in West African forest geckos (Hemidactylus fasciatus). Proceedings of the Royal Society B 277:3071-3077.

Leslie JF (1993) Fungal vegetative compatibility. Annual Review of Phytopathology 31: 127-150.

Morgan-Jones G (1985) The Diaporthe/Phomopsis complex of soybeans: Morphology. In: Conference on the Diaporthe/ Phomopsis complex of soybean, Proceedings... Fort Walton Beach, FL, USA. USDA-ARS. pp. 1-7.

Morgan-Jones G (1989) The Diaporthe/Phomopsis complex: Taxonomic considerations. In: World Soybean Research, Proceedings... Buenos Aires, Argentina. pp. 1699-1706.

Morrison D (2009) Why would phylogeneticists ignore computerized sequence alignments ? Systematic Biology 58:150158.

Mostert L, Crous PW, Kang JC, Phillips AJL (2001) Species of Phomopsis and a Libertella sp. occurring on grapevines with specific reference to South Africa: Morphological, cultural, molecular and pathological characterization. Mycologia 93:146167.

Padial JM, Miralles A, De la Riva I, Vences M (2010) The integrative future of taxonomy. Frontiers in Zoology 7:16.

Pál K, van Diepeningen AD, Varga J, Hoekstra RF, Dyer PS, Debets AJM (2007) Sexual and vegetative compatibility genes in the aspergilla. Studies in Mycology 59:19-30.

Pioli R, Morandi E, Martínez C, Lucca F, Tozzini A, Bisaro V, Hopp E (2003) Morphologic, molecular, and pathogenic characterization of Diaphorte phaseolorum variabillity in the core soybean-producing area of Argentina. Phytopathology 93:136146.

Rannala B, Yang ZH (2003) Bayes estimation of species divergence times and ancestral population sizes using DNA sequences from multiple loci. Genetics 164:1645-1656.

Rehner SA, Uecker FA (1994) Nuclear ribosomal internal transcribed spacer phylogeny and host diversity in the coelomycete Phomopsis. Canadial Journal of Botany 72:1666-1674.

Rensburg, Janse van JC, Lamprecht S, Groenewald J, Castlebury L, Crous P (2006) Characterisation of Phomopsis spp. associated with die-back of rooibos (Aspalathus linearis) in South Africa. Studies in Mycology 55:65-74

Santos JM, Correia VG, Phillips AJL (2010) Primers for matingtype diagnosis in Diaporthe and Phomopsis: Their use in teleomorph induction in vitro and biological species definition. Fungal Biology 114:255-270.

Santos JM, Vrandečić K, Cosić J, Duvnjak T, Phillips AJ (2011) Resolving the Diaporthe species occurring on soybean in Croatia. Persoonia 27:9-19.

Sinclair J, Backman P (1989) Compendium of Soybean Diseases. $3^{\text {th }}$ Ed. St. Paul, MN, USA. APS Press.

Sites JW, Marshall JC, (2003) Delimiting species: A renaissance issue in systematic biology. Trends in Ecology and Evolution 18:462-470.

Sites JW, Marshall JC (2004) Operational criteria for delimiting species. Annual Review of Ecology, Evolution and Systematics 35:199-227.

Smit WA, Knox-Davies PS (1989a) Die-back of rooibos tea caused by Diaporthe phaseolorum. Phytophylactica 21:183-188.

Smit WA, Knox-Davies PS (1989b) Comparison of Diaporthe phaseolorum isolates from rooibos tea, Aspalathus linearis. Phytophylactica 21:301-306.

Tamura K, Dudley J, Nei M, Kumar S (2007) MEGA4: Molecular Evolutionary Genetics Analysis (MEGA) software version 4.0. Molecular Biology and Evolution 24:1596-1599.

Thompson JD, Higgins DG, Gibson TJ (1994) CLUSTAL W: Improving the sensitivity of progressive multiple sequence alignment through sequence weighting, position-specific gap penalties and weight matrix choice. Nucleic Acids Research 22:4673-4680.

Udayanga D, Liu X, Crous P, Mckenzie E, Chukeatirote E, Hyde D (2012) A multi-locus phylogenetic evaluation of Diaporthe (Phomopsis). Fungal Diversity 56:157-171.

Udayanga D, Liu X, Mckenzie E, Chukeatirote E, Bahkali A, Hyde D (2011) The genus Phomopsis: Biology, applications, species concepts and names of common phytopathogens. Fungal Diversity 50:189-225.

Uecker FA (1988) A world list of Phomopsis names with notes on nomenclature, morphology and biology. Mycologia Memoir 13:1-231

Yang ZH, Rannala B (2010) Bayesian species delimitation using multilocus sequence data. Proceedings of the National Academy of Sciences, USA 107:9264-9269.

Yorinori J (1996) Cancro da haste da soja: Epidemiologia e Controle. EMBRAPA-Soja. Londrina, PR, Brazil. Embrapa Soja.

Zang L, Zou X, Zhang F, Yang Z, Ge S (2011) Phylogeny and species delimitation of the C-genome diploid species in Oryza. Journal of Systematics and Evolution 49:386-395.

Zhang AW, Riccioni L, Pedersen WL, Kollipara KP, Hartman GL 
(1998) Molecular identification and phylogenetic grouping of Diaporthe phaseolorum and Phomopsis longicolla isolates from soybean. Phytopathology 88:1306-1314.
Zhang C, Zhang F, Zou X, Yang Z (2011) Evaluation of a Bayesian coalescent method of species delimitation. Systematic Biology 60:747-761.

TPP-2013-0121

Submitted: 11 July 2013

Revisions requested: 4 November 2013

Accepted: 7 January 2014

Section Editor: Alan Wood 